\title{
MARTIN HATTALA A JEHO VKLAD DO DISKUSIE O HISTORICKOM POMERE MEDZI HLAHOLIKOU A CYRILIKOU'
}

\author{
Martin Hattala and His Contribution to the Discussion \\ on the Historical Relationship Between Glagolitic and Cyrillic
}

\author{
L’ubomír Kralčák
}

DOI: 10.17846/CL.2021.14.2.139-147

\begin{abstract}
KRALČÁK, Lubomír. Martin Hattala and His Contribution to the Discussion on the Historical Relationship Between Glagolitic and Cyrillic. The reform of standard Slovak at the beginning of the second half of the 19th century is one of the cultural milestones in Slovak history, which is inextricably linked with the name Martin Hattala. However, this important linguist, in addition to the issue of literary language, also dealt with issues of Slavic studies and especially the historical origins of Glagolitic and Cyrillic. The aim of our paper is to point out Hattala's scientific contribution to the discussion of the historical relationship between these ancient alphabetical systems. Moreover, our research is important in terms of following Hattala's attitudes at the time of new discoveries of ancient texts, which led to the gradual formation of the view that the original Slavic script constructed by Constantine the Philosopher was Glagolitic. Hattala belonged to that part of the Slavic scientific community which recognized Cyrillic as the original Slavic script, and from this scientific position he also approached individual controversial issues and newly discovered textual monuments. He expressed his attitude on the current views of well-known Russian linguists in an article focused on the analysis of the text of the monk Chrabr about letters existing in five historical transcripts. These researchers found incorrect alphabetic and numerical data in two of these transcripts testifying to the Glagolitic basis of these textual monuments. M. Hattala expressed a negative attitude to that evidence, which he justified on the one hand by the incompetence and thus the unreliability of the scriptors transcribing these monuments, and on the other by the inconsistency of current researchers in examining the disputed parts of the text. Although M. Hattala in his polemics did not give up the traditional opinion on the origin of the Slavic script, with some of his research findings he contributed to a more thorough scientific discourse on one of the basic questions of Slavic studies.
\end{abstract}

Keywords: Glagolitic, Cyrillic, alphabet, manuscript, alphabetical systems

V tomto roku si pripomíname 200. výročie narodenia Martina Hattalu, ktorý sa do našich kultúrnych dejín zapísal ako jeden z najvýznamnejších slovenských jazykovedcov. Náš článok je teda súčasne príspevkom $\mathrm{k}$ tomuto jeho významnému jubileu. ${ }^{2}$

1 Tento príspevok bol podporovaný Agentúrou na podporu výskumu a vývoja na základe Zmluvy č. APVV-16-0116.

2 Martin Hattala sa narodil 4. novembra 1821 v Trstenej. Gymnaziálne štúdiá absolvoval na Dolnej zemi. Roku 1841 bol prijatý do prípravného učitelského seminára v Bratislave, v rokoch 1842 - 1844 študoval filozofiu na arcibiskupskom lýceu v Trnave a následne sa dostal do Viedne na štúdium teológie do rímskokatolíckeho seminára známeho ako Pázmaneum. Po skončení teologických štúdií r. 1848 pôsobil ako 
Za Hattalov najväčší prínos sa tradične považuje jeho priama účast' na reforme štúrovskej spisovnej slovenčiny a zároveň autorstvo gramatiky Krátka mluvnica slovenská (1852), ${ }^{3}$ ktorá sa stala základným textom tejto reformy. Zásluhy $\mathrm{M}$. Hattalu o slovenčinu sú však širšie, a to aj napriek tomu, že väčšiu čast života strávil v Čechách, kde pôsobil od r. 1854 na pražskej univerzite ako profesor slovanskej filológie. Okrem spomínanej reformnej gramatiky ovplyvnil predstavy a úvahy o spisovnej slovenčine a jej štruktúre aj dalšími dielami. Po vystúpení M. M. Hodžu s novým návrhom na hláskoslovnú a ortografickú podobu spisovnej slovenčiny oproti štúrovčine v diele Epigenes slovenicus (1847) M. Hattala sa v recenzii na toto dielo v Orle tatránskom (1848) postavil v zásadných otázkach na Hodžovu stranu a napokon o dva roky neskôr vydal latinsky písanú gramatiku s vlastnou predstavou o reforme spisovného jazyka pod názvom Grammatica linguae slovenicae collatae cum proxime cognata bohemica (1850). Na základe svojich nových porovnávacích výskumov už ako mimoriadny profesor na pražskej univerzite vydal aj dalšiu komparatívnu gramatiku Srovnávací mluvnice jazyka českého a slovenského (1857). O exaktný opis spisovnej slovenčiny sa zaslúžil aj v 60. rokoch gramatikami slovenského jazyka (Mluvnica jazyka slovenského, 1864, a Mluvnica jazyka slovenského. Diel druhý. Skladba, 1865). Tieto gramatiky mali rozhodujúci význam pre ustalovanie spisovnej slovenčiny v druhej polovici 19. storočia.

Ďalšiu významnú čast' jeho jazykovedného diela tvoria práce z oblasti slavistiky a historicko-porovnávacej jazykovedy. Osobitnou oblastou Hattalovho vedeckého záujmu sa stali otázky paleoslavistiky či slavistickej komparatistiky, kam možno zaradit aj jeho vedecké náhlady na pôvodnost’ slovanského písma.

V tomto príspevku sa sústredíme na analýzu vedeckého vkladu M. Hattalu do riešenia otázky vztahu medzi hlaholikou a cyrilikou z hladiska ich historickej pôvodnosti. Do tejto diskusie sa zapojil dvoma časopiseckými príspevkami, ktoré vyšli r. 1858. Prvým bola stat polemizujúca o význame rozpravy mnícha Chrabra $O$ písmenách z hladiska nárastu počtu názorov preferujúcich historické prvenstvo hlaholiky oproti cyrilike. Druhým bol nemecky písaný text, v ktorom Hattala pomerne osobne vykladá svoj postoj k otázke pôvodu slovanského písma.

\section{Diskusie o historickej pôvodnosti slovanskej alfabety v 2. tretine 19. sto- ročia}

Otázka historickej pôvodnosti dvoch grafických sústav viažucich sa na starosloviensky jazyk nejestvovala $\mathrm{v}$ počiatkoch formovania sa slavistiky ako vedecký problém, pretože za pôvodné Konštantínom zostavené slovanské písmo sa od začiatku všeobecne pokladala cyrilika. Toto sprvu nesporné poznanie, ktorého zástancom bol už sám zakladatel slavistiky J. Dobrovský, sa začalo oslabovat koncom 18. storočia, no najmä po vystúpeniach niektorých bádatel'ov v druhej tretine 19. storočia, ktoré sa spájajú s pribúdajúcimi objavmi dovtedy neznámych hlaholských textov a najmä po ich exaktnejších výskumoch. Jedným z najvýznamnejších krokov, ktorý viedol k dôležitému

kaplán v Hodruši a v Bzovíku. Začas bol učitelom gymnázia, pričom v snahe dosiahnut výnimku od predpísaných skúšok učitelskej spôsobilosti vypracoval odborný spis o hláskosloví českého a slovenského jazyka, ktorý muselo schválit ministerstvo vo Viedni. Prácu predložil r. 1853 a posudzoval ju P. J. Šafárik, ktorý na jej základe odporúčal Hattalu na Katedru slovanskej filológie v Prahe. Tu následne absolvoval štúdium, aby sa mohol habilitovat v odbore slovanská filológia, čo sa mu úspešne podarilo $\mathrm{r}$. $1854 \mathrm{av}$ tom istom roku bol v rovnakom odbore menovaný za mimoriadneho profesora. Roku 1861 bol M. Hattala vymenovaný za riadneho profesora na pražskej univerzite. Zomrel 11. decembra 1903 v Prahe (k tomu porov. Jóna, 1971, 13-28).

3 Text je bez mena autora. Úvod podpísali M. M Hodža, J. M. Hurban, J. Palárik, Ondrej Radlinský, Ludevít Štúr a Štefan Závodník. Dnes sa všeobecne prijíma, že autorom textu gramatiky bol M. Hattala. 
prelomu v tejto otázke, bolo vydanie hlaholskej pamiatky Glagolita Clozianus (tzv. Clozov zborník) B. Kopitarom (1836). Kopitar porovnával túto pamiatku s cyrilským Ostromirovým evanjeliárom a na tomto základe dospel k záveru, že Glagolita Clozianus je ak nie starším, tak aspoň rovnako starým textom ako Ostromirov evanjeliár, ktorý bol v tom čase dokázatel’ne najstarším cyrilským a vôbec staroslovienskym rukopisom s pôvodným označením roku svojho vzniku. ${ }^{4}$ Treba však dodat', že hoci išlo vskutku o významný posun v chápaní pomeru oboch slovanských abecied, Kopitarove úsudky ešte neviedli k názoru, že hlaholika bola pôvodným slovanským písmom starším ako cyrilika. Obidve alfabety sa týmto vlastne iba stavali historicky na roveň, pričom sám Kopitar (1836, III) sa domnieval, že mali rozdielnu spoločenskú funkciu - cyrilika mohla byt’ sakrálnym a hlaholika civilným písmom.

Kopitarovo vydanie dovtedy neznámej hlaholskej pamiatky a na jej materiáli založené úvahy o podobe pôvodného slovanského písma sa stali novým, zásadným impulzom diskusií o starobylosti oboch alfabetických sústav. Ozvali sa súhlasné i odmietavé hlasy. Najvýraznejší súhlas s pôvodnostou hlaholiky vyslovil vzápätí (1836) významný nemecký filológ J. Grimm, ktorý sa pri tom opieral o paleografické špecifiká hlaholiky dokazujúce, že táto abeceda bola zostavená v krátkom čase a je zjavné, že ju možno chápat ako dielo jednotlivca, a teda pripísat ju Konštantínovi (Vajs, 1932, 26). Oproti tomu názory odmietajúce Kopitarove a Grimmove tvrdenia sa zdvihli predovšetkým medzi ruskými slavistami, ako boli napr. P. I. Prejs (1843), I. I. Sreznevskij (1848), O. M. Bodanskij (1855). Medzi odporcov historického prvenstva hlaholiky vo vztahu k cyrilike patril pôvodne aj P. J. Šafárik. Napríklad v stati Rozkvět slovanské literatury v Bulharsku $(1848,4)$ síce pripúštal výraznejšiu starobylost' hlaholiky než kedysi Dobrovský, no za staršiu ako cyrilika ju bez presvedčivých písomných dokladov odmietal uznat. Ešte v spise Památky hlaholského písemníctví Šafárik (1853, XXXIX) vyjadruje presvedčenie, že cyrilské písomníctvo je pôvodné, a teda staršie ako hlaholské. Podla neho Kopitarova domnienka o vzniku hlaholských písmen „ještě i ted’ na nejistotě zawěšena jest".

Zásadný posun v Šafárikových názoroch napokon spôsobil náhodný objav dvoch hlaholských pergamenových listov, dnes známych pod označením Pražské zlomky, ktorý sa podaril profesorovi histórie K. Höflerovi roku 1855. Túto pamiatku pod názvom Glagolitische Fragmente vydal spoločne s P. J. Šafárikom (Höfler - Šafařík, 1857), ktorý ju datoval do prvej polovice 10. storočia. Išlo o liturgickú pamiatku východného obradu z jazykového i paleografického hladiska velmi špecifickú a starobylú so zretel'nými západoslovanskými jazykovými prvkami. Bol to v porovnaní s ostatnými hlaholskými textami výnimočný doklad, ktorý zohral vo vývoji Šafárikovho ponímania veku hlaholiky a jej pomeru k cyrilike zásadný význam. Vo svojom komentári k publikovanej pamiatke naznačuje zmenu svojho postoja a vyzýva na vedeckú diskusiu o tejto otázke v záujme jej skorého riešenia. Podla neho niet divu, že medzi slovanskými vedcami neexistuje jednota $\mathrm{v}$ názore na relatívny vek a vzájomný vztah dvoch slovanských abecied. Dúfa však, že objav a zverejnenie týchto dôležitých fragmentov prinúti ostatných vedcov venovat’ svoju vynaliezavost’ a usilovnost tomuto zaujímavému problému, aby čo najskôr našli jeho konečné riešenie (Höfler Šafařík 1857, 57).

Na objav Pražských zlomkov reagoval v krátkom čase a s výrazným zaujatím sa o starobylost’ hlaholiky J. I. Hanuš (1857), ktorý priamo označil Šafárikov výklad starobylosti Pražských zlomkov za zásadný pre uznanie historickej pôvodnosti hlaholiky v pomere k cyrilike. Pritom argumentoval na jednej strane starobylostou písma, ktoré Šafárik označil za špecifický typ hlaholiky, na druhej strane starobylostou jazykových znakov, ktoré sú navyše západoslovanské, čo žiadna dovtedy

4 Ostromirov evanjeliár je jednou z najvýznamnejších pamiatok ruskej redakcie staroslovienčiny. Bol napísaný cyrilikou v novgorodskom Sofijskom chráme v rokoch 1056 - 1057. V polovici 19. storočia bola táto pamiatka akýmsi meradlom starobylosti cyriliky v porovnaní s hlaholikou. 
nájdená pamiatka $\mathrm{v}$ takom rozsahu a systémovom zastúpení neobsahovala. Hanuš k tomu pridáva d’alšie zväčša už predtým vyslovené argumenty, napr. že Konštantín zostavil originálnu abecedu, čomu nemôže zodpovedat cyrilika, ale iba hlaholika. Odkazuje tiež na staršie Šafárikove zistenia (Památky hlaholského písemnictví), že vo viacerých cyrilských rukopisoch sa nachádzajú hlaholikou zapísané jednotlivé slová či písmená, príp. zdobené iniciály, čo je dôkazom prepisovania cyrilských textov zo starších zaznamenaných hlaholikou, avšak naopak, na prepisovanie textov z cyriliky do hlaholiky sa nenašli žiadne dôkazy.

\section{Hattalov vklad do diskusie o historickej pôvodnosti hlaholiky a cyriliky}

Do takto rozvinutých diskusií a polemík o pôvodnosti slovanských abecedných sústav vstúpil aj M. Hattala, patriaci k tej časti slavistickej vedeckej obce, ktorá uznávala za prvotné slovanské písmo cyriliku a ku ktorej sa svojimi pôvodnými náhladmi zarad’oval aj samotný Šafárik. $\mathrm{V}$ tejto súvislosti je pomerne zaujímavé, že hoci spomínané nové poznatky a s nimi spojené impulzy na prehodnotenie tradičného chápania hlaholiky prinieslo na začiatku druhej polovice 19. storočia predovšetkým Šafárikovo vydanie Pražských zlomkov, Hattala na toto vydanie, resp. na Šafárikove zistenia a analýzy nijako priamo nereagoval. Pravdupovediac, vedecky objektívna Šafárikova analýza podaná vo vydaní Pražských zlomkov ani nedávala reálnu možnost', aby sa stala predmetom kritických posúdení. Treba však zdôraznit, že Šafárik tu ešte neprišiel so zavrhnutím pôvodnej hypotézy o historickom prvenstve cyriliky vo vztahu k hlaholike, ale iba vyzýval na d’alšiu vedeckú diskusiu.

\subsection{Chrabrova rozprava $O$ písmenách}

Hattalovým strategickým vedeckým cielom bolo hájit tradičný názor o historickom prvenstve cyriliky v porovnaní s hlaholikou. K tomu si ako prostriedok zvolil polemiku s tými názormi preferujúcimi pôvodnost' hlaholiky, ktorých autori sa opierali o nejasné či sporné časti v niektorých historických variantoch Chrabrovej rozpravy O písmenách. ${ }^{5}$ Vystúpenie M. Hattalu malo formu časopiseckého príspevku s názvom Mnich Chrabr (1858), v ktorom išlo o konkrétnu reakciu na práce ruských slavistov, najmä I. I. Sreznevského, O. M. Bod’anského či českého mytológa J. I. Hanuša.

Hattala vo svojej stati rieši najprv otázku sumarizácie známych vydaní Chrabrovej rozpravy, ale aj mieru ich historickej vzácnosti. K štyrom vtedy známym publikovaným variantom textov (Synodálny, Vratislavský, Moskovský a Savinský) ${ }^{6}$ doplňuje novšie objavený historický prepis, vydaný V. S. Karadžićom (1857), ktorý označil ako Srbský.

5 Paleoslavistická pamiatka, známa ako rozprava či rozprávanie mnícha (černorizca) Chrabra pod názvom O písmenách; patrí k historicky najčastejšie prepisovaným staroslovienskym pamiatkam, pričom dodnes sa zachovala vo viac ako 70 variantoch historických odpisov (porov. k tomu Kuev, 1967). Ide síce o kratšiu, no neobyčajne fundovanú rozpravu o zostavení prvého slovanského písma Konštantínom. Toto vzácne historické svedectvo sa však stalo aj prostriedkom na dohady, diskusie a polemiky o historickej prvotnosti hlaholiky či cyriliky, pretože z pamiatky priamo nevyplýva, ktorú abecedu Konštantín zostavil.

6 Za najstarší z nich sa pokladal rukopis označovaný ako Synodálny podla príslušnosti k Synodálnej bibliotéke v Moskve (prepísaný bol r. 1348), Vratislavský má označenie podla miesta vtedajšieho uchovávania v Bibliotéke vratislavského Gymnázia sv. Magdalény), Moskovský (Hattalom označený ako Akademický), ktorý sa považuje aj dnes za obsahovo i jazykovo najvzácnejší, je súčastou zbierok Moskovskej duchovnej akadémie (15. storočie), Savinský dostal názov podla toho, že bol uchovávaný v Savinskom kláštore (jeho prepis vznikol tiež v 15. storočí). 
Zároveň z jazykovo-historického hladiska spomedzi týchto rukopisov M. Hattala (1858, 118 n.) poukázal na dva, Moskovský a Srbský, na ktoré sa najviac sústredili bádatelia považujúci ich za prepisy z hlaholskej predlohy. Toto ich označenie odkazovalo na výraznú starobylost̉ hlaholiky ako abecedy, a to bud' nepriamo (Bod’anský a Sreznevský pri posudzovaní Moskovského prepisu), alebo priamo aj s explicitným vyslovením sa o jej historickej pôvodnosti (Hanuš s odkazom na Srbský prepis). Podla M. Hattalu však o historickej vzácnosti týchto rukopisov nemožno hovorit: „Mně naproti tomu nepovedlo posud přesvědčiti se, žeby rukopisy právě spomenuté v skutku z originálu glag. pocházely, ačkoli sem všemožně o to stál.“ V porovnaní so zvyšnými tromi prepismi argumentuje najmä ich niektorými odlišnými slovnými tvarmi, znejasňujúcimi niekedy význam vety.

Ťažiskom argumentácie v rámci tejto polemiky sa však pre Hattalu $(1858,119$ n.) stala otázka zachovanosti abecedárov, ktoré sú $\mathrm{v}$ jednotlivých prepisoch Chrabrových textov obsiahnuté v rozličnom rozsahu. Chrabr tu vypočítava slovanské písmená, ktoré zostavil Konštantín, pričom

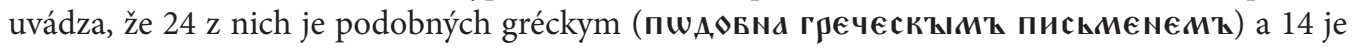

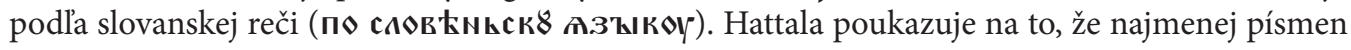
abecedy uvádza Synodálny prepis, širší súbor obsahujú Savinský a Vratislavský, ktoré sa v ich výpočte zhodujú. Od všetkých sa však líši Moskovský, ktorý obsahuje v tejto pasáži špecifické údaje. Týkajú sa jednak počtu písmen, jednak spôsobu zápisu pri vyratúvaní písmen zostavených podla slovanskej reči.

Kritickým miestom, ktoré si tu osobitne všíma O. M. Bodanskij (1855, XXXII - XXXIII) a predovšetkým preň označuje tento prepis za „hlaholskýc, je uvedenie súhrnného počtu písmen podla slovanskej reči, ktoré nasleduje hned’ po súbore písmen podobných gréckym písmenám.

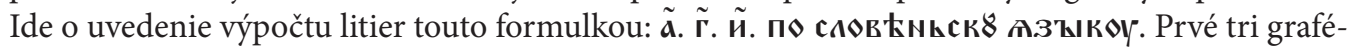
my sú akoby pokračujúcimi písmenami predchádzajúceho výpočtu písmen podobných gréckym, no podla Bod’anského písmeno ã na začiatku nemá mat nad sebou titlu, pretože ide o spojku $a$. Zvyšné dve písmená sú číselným záznamom a ich označenie titlami je náležité. Tak, ako sú zapí-

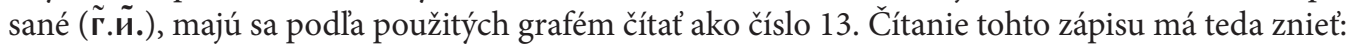
„a trinásţ podla slovanskej reči“.

Zásadný problém je však v tom, že v ostatných skúmaných prepisoch je jednoznačne uvedené,

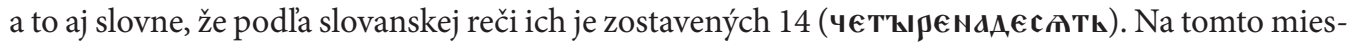
te je teda v prepise chyba, ku ktorej podla Bod’anského došlo práve preto, že text bol prepisovaný z hlaholskej predlohy. Rozdielnost' historických slovanských abecied je nielen vo výrazne odlišnej forme, ale aj v rozdielnej číselnej platnosti ich litier. Je to spôsobené tým, že kým hlaholika mala stanovenú vlastnú číselnú hodnotu grafém, cyrilika ju v plnom rozsahu prebrala z gréckej abecedy. Tým vznikol rozdiel už na prvých štyroch pozíciách označujúcich čísla od 1 po 4 , pretože grécka alfabeta, súc vzorom pre cyriliku, nemá grafému označujúcu hlásku [b]. V hlaholskej sústave $\mathfrak{T}=1, \boldsymbol{\Psi}=2, \boldsymbol{P}=3, \boldsymbol{\%}=4$, v cyrilskej $\mathbf{A}=1, \mathbf{6}-$ nemá žiadnu číselnú hodnotu, $\mathbf{6}=2, \mathbf{\Gamma}=$

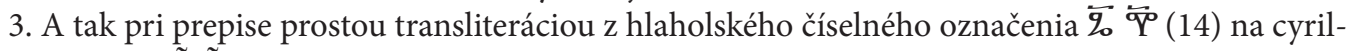
skú grafiku $\tilde{\boldsymbol{\Gamma}} \tilde{\mathbf{u}}$ mení sa takéto číselné označenie na hodnotu 13. Správne označenie hodnoty 14 v cyrilike má mat’ grafemická podobu $\tilde{\mathbf{A}} \tilde{\mathbf{H}}$, príp. $\widetilde{\mathbf{A} \mathbf{H}}$. Uvedená predpokladaná číselná zámena teda môže byt vážnym svedectvom o prepisovaní tohto manuskriptu zo starobylej predlohy, ktorá bola písaná hlaholikou.

M. Hattala však takýto predpoklad neprijíma. Pozoruhodné je, akými argumentmi pritom vo svojej polemike pracuje. Upozornil na to $(1858,120)$, že bádatelia, ktorí spomínané kritické miesto analyzovali, neboli dôslední, pretože na jednej strane sa síce podrobne zaoberali spornou sumárnou číselnou hodnotou, no na druhej strane vlastne ani nespočítali súbor tam uvedených grafém podla slovanskej reči. A tak vyzýva tých, ktorí sa takouto analýzou zaoberali, aby „znova počítati ráčili, neučinili-li to již dříve. Co když se stane, nenajdou jich tam ani 14 ani 13 než 15 !“ 
Tento jeho postreh je správny, totiž písmen je v spomínanom rade uvedených vskutku 15, pričom aj ich skladba je v porovnaní s ostatnými prepismi špecifická: $\tilde{\mathbf{k}}, \tilde{\boldsymbol{K}}, \tilde{\mathbf{s}}, \tilde{\mathbf{n}}, \tilde{\mathbf{u}}, \tilde{\mathbf{4}}, \tilde{\mathbf{W}}, \tilde{\mathbf{k}}, \boldsymbol{ш} \tilde{\mathbf{k}}, \boldsymbol{\mathbf { \mathbf { k } }}, \tilde{\mathbf{k}}$, $\tilde{\mathbf{k}}, \mathbf{i}, \tilde{\boldsymbol{\aleph}}, \tilde{\mathbf{A}}$.

Hattala má nepochybne pravdu, ked' dalej dôvodí tým, že v tejto časti je prepis z hladiska skladby málo dôveryhodný, pretože je tu $\Lambda$, ktoré nepatrí sem, ale do radu písmen podobných gréckym, medzi ktorými je v tomto texte aj uvedené. Ďalej je tu dvakrát zaznamenaná graféma ha ba sú tu aj

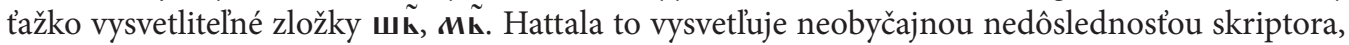
resp. jeho zjavnou neznalostou hlaholských písmen. $\mathrm{Z}$ toho vyvodzuje, že takýto prepisovatel' ako svedok existencie pôvodnej hlaholskej predlohy je preňho nevierohodný.

Tieto nejasnosti navrhuje riešit správnou interpretáciou grafém vo vztahu k ich hláskovým korelátom. Podla neho nie je ničím pevne dané, že Konštantín stvoril z 38 písmen 24 podobných gréckym a 14 podla slovanskej reči, lež správnejšie je predpokladat číselný pomer 25 a 13. Vo svojej rekonštrukcii súboru staroslovienskych písmen (a zároveň hlások) podla slovanskej reči vychádza z náslovných grafém (hlások), teda začiatočných písmen slov, ktoré Chrabr vymenúva ako nezaznamenatelné pomocou gréckej alfabety. Gréčtina totiž pre ich začiatočné hlásky nemá

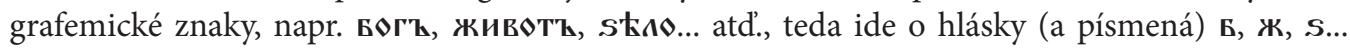
$\mathrm{Z}$ týchto náslovných písmen zostavil desiatku znakov podla slovanskej reči, a to $\mathbf{6}$, ж,, $\mathbf{S , ~ ц , ~ ч , ~ ш , ~}$

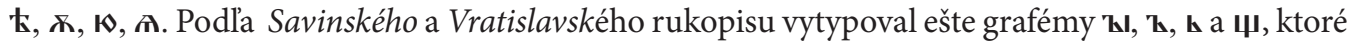
k nim doplnil. Vzápätí však uviedol korektné paleografické dôvody, prečo je graféma щ historicky mladšia a do pôvodnej slovanskej abecedy nepatrí. A tak na základe tejto rekonštrukcie mu naostatok vyšlo v konečnom súčte 13 písmen podla slovanskej reči. Problém ním navrhovaného počtu 25 písmen podobných gréckym rieši už pomerne jednoducho, a to podla neho potrebným doplnením o cyrilské písmeno $\mathbf{v}$ (hlah. g, t. j. yžica) podla gréckeho $v$.

Vo zvyšnej časti svojej state Hattala vyslovuje odmietavý postoj aj voči názorom J. I. Hanuša, podla ktorého iba nedávno vydaný tzv. Srbský rukopis nesie v sebe nepochybné svedectvo, že má bezprostredný súvis s východiskovým hlaholským textom. Hanuš $(1857,11)$ si je pritom vedomý značnej odvodenosti, nepôvodnosti, resp. nízkej miery prekrývania sa jeho obsahu s obsahmi ostatných prepisov. Opiera sa však o náslovné, na slovných príkladoch založené vypočítanie písmen celej Konštantínovej abecedy, ktoré je obsiahnuté v Srbskom rukopise. Pri svojom presvedčení o hlaholskej predlohe pôvodnej Chrabrovej rozpravy dôvodí Hanuš hlaholským poradím vymenovaných grafém od a po X. V tomto poradí je graféma $\mathbf{\Gamma}$ uvedená dvakrát, a to prvýkrát na svojom mieste ро в ako štvrtá v poradí a druhýkrát na dvanástom mieste, a to tam, kde sa v hlaholskej alfabete nachádza o $P$ (děrv), ktoré cyrilská abeceda nepoznala. Je to teda vážny dôkaz toho, že predlohou tu bol hlaholský text. Skriptor vlastne hlaholské o $P$ nahradil cyrilskou literou

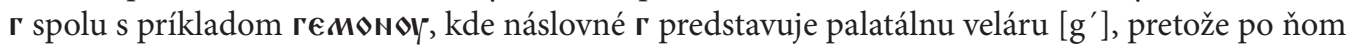
nasleduje predný vokál [e]. Hattala takýto argument rázne odmieta ako dôvod pre to, že by Srbský prepis pochádzal z hlaholského originálu. Odkazuje pritom na skutočnost', že Srbi oddávna používali túto grafému na mieste $d j$.

M. Hattala naostatok zhrnujúco poznamenáva, že pokial' ide o prepisy Srbský a Moskovský, pokladá ich za texty v mnohom chybné, o ktoré nebude mat dôvod stát ani v budúcnosti. Oproti tomu Savinský a Vratislavský prepis predovšetkým vd’aka podrobnému výpočtu abecednej sústavy podla neho neomylne preukazujú svoj vztah k cyrilike. Napokon sa k otázke pôvodnosti slovanského písma vyslovuje jednoznačne v prospech cyriliky: „Po straně všeho, čím posud svědectví Chrabrovo ke glagolici bylo obracováno, stojí pouze voluntas pro ratione (Hattala 1858, 28). 


\subsection{Hattalov postoj k otázke pôvodu slovanského písma}

Druhým príspevkom M. Hattalu do diskusie o pôvodnosti slovanského písma bol článok v periodiku Kritische Blätter für Literatur und Kunst, ktorý vyšiel v rovnakom roku ako jeho stat' venovaná Chrabrovmu textu, a to pod názvom Mein Standpunkt in der Frage über den Ursprung der slavischen Schrift (Môj postoj k otázke pôvodu slovanského písma) (1858).

Tento Hattalov príspevok bol predovšetkým reakciou na Hanušov prehladový článok v rovnakom periodiku o najnovšej literatúre v Rakúsku (1858). V tomto príspevku Hanuš okrem iného víta rozprúdenie diskusie o historickosti hlaholiky, no s Hattalovou odmietavou kritikou jej historických preferencií nemôže súhlasit’. S velkou nádejou však očakáva prelom v chápaní tejto otázky po skvelom vystúpení P. J. Šafárika v práci O pôvode a domovine hlaholiky (1858).

Hattalova reakcia tu sčasti vyznieva osobne, $\mathrm{v}$ istom zmysle ako vyrovnávanie sa s cielmi vlastného vedeckého bádania a s prístupom $\mathrm{k}$ nemu, ako aj $\mathrm{s}$ chápaním sporných otázok slavistiky, najmä s otázkou pôvodu hlaholiky a cyriliky. V tomto do istej miery netypickom vedeckom pojednaní akoby sa Hattala vyrovnával aj so svojím vztahom k Šafárikovi. Ten bol vždy preňho váženou vedeckou autoritou, s ktorej názormi a zisteniami nikdy nepolemizoval. Tu musel zaujat' aj postoj k Hanušovej výčitke, prečo sa už dávnejšie nevenoval diskusiám o pôvodnosti slovanskej abecedy a nevyslovoval svoj vlastný názor, ktorý mohol byt’ odlišný od Šafárikovho. Hattala (1858, 115) na to odpovedá, že vnímal ako mocne a vytrvalo bol Šafárik zaujatý otázkou o pôvode a vzájomnom vztahu dvoch slovanských abecied, čoho výsledkom je aj jeho posledná práca o pôvode hlaholiky. Zdôraznil, že aj za priaznivejších okolností by sa zdržal zasahovania do Šafárikovho dlhoročného výskumu v tejto otázke tak bezprostredne, ako sa Hanuš domnieval, že by mal urobit. M. Hattala však naostatok priznáva, že napriek novým Šafárikovým poznatkom je stále velmi daleko od predpokladu, že hlaholika je pôvodné slovanské písmo.

\section{Na záver}

Ťažiskom tohto príspevku bola analýza vedeckých názorov M. Hattalu, ktorými prispel do diskusie o riešení otázky vzțahu medzi hlaholikou a cyrilikou z hladiska ich historickej pôvodnosti. Pri tejto analýze bolo dôležité načrtnút historický vedecký kontext, do ktorého Hattala v polovici 19. storočia svojou polemikou vstúpil. Náš bližší pohlad ukázal, že sa zapojil do týchto diskusií v čase, ked' sa tradičný názor na cyriliku ako pôvodné slovanské písmo začal oslabovat' v jej neprospech a v prospech hlaholiky. Išlo o dôsledok nových objavov dovtedy neznámych hlaholských textov a ich exaktnejších výskumov, ktoré poukazovali na ich starobylost', a teda aj starobylost' hlaholského písma. Hattala patril k tej časti slavistickej obce, ktorá uznávala za prvotné slovanské písmo cyriliku a z tejto vedeckej pozície pristupoval aj k jednotlivým sporným otázkam a novoobjaveným textovým pamiatkam. Svoje postoje a názory na aktuálne vystúpenia najmä významných ruských slavistov vyslovil v článku zameranom na analýzu rozpravy mnícha Chrabra $O$ písmenách existujúcej v piatich známych historických odpisoch. Ruskí slavisti I. I. Sreznevskij, O. M. Bod’anskij a domáci bádatel' I. J. Hanuš nachádzali v dvoch z týchto odpisov chybné alfabetické a numerické údaje svedčiace podla nich o hlaholských predlohách týchto pamiatok. M. Hattala vyslovil k uvedeným dôkazom odmietavé stanovisko, ktoré odôvodňoval na jednej strane nekompetentnostou, a teda nevierohodnostou skriptorov prepisujúcich tieto pamiatky, na druhej strane nedôslednostou súčasných bádatel’ov pri skúmaní sporných častí textu. V druhom svojom článku viac-menej zopakoval svoj záporný postoj k preferenciám hlaholiky ako pôvodného slovanského písma. Zároveň sa vyznal zo svojho vedeckého rešpektu pred prácou a dielom P. J. Šafárika, čím odôvodňoval absenciu vlastnej polemiky s jeho novšími či staršími názormi. 
Naostatok možno konštatovat, že M. Hattala svojím polemickým vystúpením k otázkam pôvodnosti slovanského písma sa síce pridŕžal tradičného, tažko udržatelného názoru o historickej pôvodnosti cyriliky, no niektorými svojimi bádatel’skými zisteniami prispel k dôkladnejšiemu priebehu vedeckého diskurzu o jednej zo základných otázok paleoslavistiky.

\section{REFERENCES}

Bod’anskij, Osip Maksimovič. 1855. O vremeni proischoždenija slavianskich pismen. Moskva.

Hanuš, Ignac Jan. 1857. Sv. Kyril nepsal kyrilsky než hlaholsky. Z pojednání Královské české společnosti nauk. Praha.

Hanuš, Ignac Jan. 1858. Rückblick auf die jüngste Literatur von und über Oesterreich. In: Kritische Blätter für Literatur und Kunst 1858, 68-69.

Hattala, Martin. 1850. Grammatica linguae slovenicae collatae cum proxime cognata bohemica. Archi-Dioecesis Strigoniensis Presbytero, Cooperatore Hodrusbányensi. Schemnicii (Banská Štiavnica).

Hattala, Martin. 1857. Srovnávací mluvnice jazyka českého a slovenského. Praha.

Hattala, Martin. 1858. Mnich Chrabr. Př́spěvek k objasnení původu písma slovanského. In Časopis Musea královstí Českého 1/ 117-129.

Hattala, Martin. 1858. Mein Standpunkt in der Frage über den Ursprung der slavischen Schrift. In Kritische Blätter für Literatur und Kunst 27, 63-68, 112-115.

Hattala, Martin. 1864. Mluvnica jazyka slovenského. Pešt'.

Hattala, Martin. 1865. Mluvnica jazyka slovenského. Diel druhý. Skladba. Banská Bystrica.

Höfler, Adolf Constantin - Šafařík, Paul Joseph. 1857. Glagolitische Fragmente. Praha.

Jóna, Eugen. 1971. Život a dielo Martina Hattalu. In: Martin Hattala 1821 - 1903. Vydal Prípravný

výbor osláv 600 rokov mesta Trstenej a 100 rokov Gymnázia v Trstenej. Trstená, 13-28.

Karadžić, Vuk Stefanović. 1857. Primjeri srpsko-slavenskoga jezika. U Beču.

Kopitar, Barholomaeus. 1836. Glagolita Clozianus. Vindobone.

Krátka mluvnica slovenská. 1852. V Prešporku.

Kuev, Kujo M. 1967. Černorizec Chrabăr. Sofija.

Prejs, Petr Ivanovič. 1843. O glagol'skoj pismennosti. In Žurnal Ministerstva narodnago prosveščenija XXXVII, 184-238.

Sreznevskij, Izmail Ivanovič. 1848. Drevnija pismena slavianskija. In Žurnal Ministerstva narodnago prosveščenija LIX, 18-66.

Šafařík, Pavel Josef. 1848. Rozkvět slovanské literatury v Bulharsku. In Časopis Českého museum 22, 4.

Šafařík, Pavel Josef. 1853. Památky hlaholského písemnictví. Praha.

Šafařík, Paul Joseph. 1858. Über den Ursprung und die Heimath des Glagolitismus. Prag.

Vajs, Josef. 1932. Rukovět hlaholské paleografie. Uvedení do knižního písma hlaholského. Praha. 
prof. PaedDr. Lubomír Kralčák, PhD.

Constantine the Philosopher University in Nitra

Faculty of Arts

Department of Slovak Language and Literature

Štefánikova 67

94974 Nitra

Slovakia

lkralcak@ukf.sk

ORCID ID: 0000-0002-2550-4366

WOS Researcher ID: AAP-6381-2020

SCOPUS Author ID: 55332638700 